\title{
Generation of Mycoplasma hominis gene- targeted mutants by targeting-induced local lesions in genomes (TILLING)
}

S. Pereyre ${ }^{1,2,3^{*}}$ (D) C. Bénard ${ }^{1,2,3}$, C. Brès ${ }^{4,5}$, C. Le Roy ${ }^{1,2}$, J. P. Mauxion ${ }^{4,5}$, F. Rideau ${ }^{1,2}$, P. Sirand-Pugnet ${ }^{4,5}$, B. Henrich ${ }^{6+}$ and C. Bébéar ${ }^{1,2,3+}$

\begin{abstract}
Background: Mycoplasma hominis is a human urogenital pathogen involved in gynaecological, neonatal and extragenital infections. However, no versatile genetic tools are currently available to study the pathogenicity of this bacterium. Targeting-Induced Local Lesions IN Genomes (TILLING) is a reverse-genetic method that combines point mutations induced by chemical mutagenesis with a DNA screening technique. We used ethyl methanesulfonate (EMS) that introduces C-G to T-A transition mutations to generate a library of $M$. hominis mutants. As a proof of concept, mutagenized organisms were screened for mutations in two target genes previously associated with the mycoplasma pathogenicity, the vaa gene encoding an adhesin lipoprotein and the oppA gene encoding the main ectoATPase of the bacterium. The resulting mutants were evaluated using functional assays, an adhesion to HeLa cell assay for vaa-mutants and an ATPase activity test for oppA-mutants.
\end{abstract}

Results: A 1200-clone library was generated by exposing M. hominis PG21 to $9 \mathrm{mg} / \mathrm{mL}$ EMS for $3 \mathrm{~h}$. To identify mutants of interest, targeted gene fragments were amplified, heat-denatured, slowly reannealed and digested with the mismatch-specific endonuclease ENDO1. If multiple alleles were present in the PCR amplicons, these alleles formed heteroduplexes during reannealing that were specifically cleaved by ENDO1 at mismatching positions. A total of four vaa-mutants and two oppA-mutants harbouring missense mutations were obtained and fully sequenced. Zero to eight additional mutations were identified in the genomes of each mutant. The vaa-mutants were tested for adhesion to immobilized HeLa cells but their adhesion was not significantly different from the adhesion of M. hominis PG21. One of the two oppA-mutants that were tested for ATPase activity presented a higher affinity for its ATP substrate than the parental strain.

Conclusion: For the first time, we demonstrated that M. hominis gene-targeted mutants could be successfully obtained using this TILLING strategy. In the absence of robust genetic tools for studying M. hominis, the TILLING strategy that can target any gene of the genome could help to elucidate gene functions and to better understand the pathogenesis of this human pathogenic species.

Keywords: Mycoplasma hominis, Chemical mutagenesis, Ethyl methanesulfonate, TILLING

\footnotetext{
*Correspondence: sabine.pereyre@u-bordeaux.fr

${ }^{\dagger}$ B. Henrich and C. Bébéar contributed equally to this work.

'USC-EA 3671 Mycoplasmal and Chlamydial Infections in Humans, University

of Bordeaux, Campus Bordeaux Carreire, 146 rue Léo Saignat, 33076

Bordeaux Cedex, France

2USC-EA 3671 Mycoplasmal and Chlamydial Infections in Humans, INRA,

Bordeaux, France

Full list of author information is available at the end of the article
}

(c) The Author(s). 2018 Open Access This article is distributed under the terms of the Creative Commons Attribution 4.0 International License (http://creativecommons.org/licenses/by/4.0/), which permits unrestricted use, distribution, and reproduction in any medium, provided you give appropriate credit to the original author(s) and the source, provide a link to the Creative Commons license, and indicate if changes were made. The Creative Commons Public Domain Dedication waiver (http://creativecommons.org/publicdomain/zero/1.0/) applies to the data made available in this article, unless otherwise stated. 


\section{Background}

Mycoplasma hominis is a human urogenital pathogen involved in gynaecological, neonatal and extra-genital infections [1]. The genome of the reference strain, $M$. hominis PG21, is the second smallest genome among self-replicating free-living organisms [2]. Although a conjugal transfer of the transposon Tn916 from Streptococcus faecalis to M. hominis was reported 30 years ago [3], no versatile genetic tools are currently available for this species. Whereas Mycoplasma arthritidis, a phylogenetically closely related species belonging to the same Hominis group, has successfully been transformed using the PEG method [4], all attempts to transform $M$. hominis using either PEG or electroporation methods, as well as transposons, suicide plasmids or replicative plasmids have failed. Only one study reported the transformation of $M$. hominis by the plasmid pAM120 using electroporation in the 2000s [5], but the experiments could not be reproduced. A cutting-edge synthetic biology approach, which consists of cloning and subsequent engineering of $M$. hominis genome in yeast is currently under development but the back transplantation of the genome from yeast to a recipient bacterium has not been achieved yet [6]. The lack of genetic engineering tools for $M$. hominis has limited our capacity to modify its genome in order to elucidate gene functions and to understand its pathogenesis.

Chemical mutagenesis methods may offer an interesting alternative method to modify the genome of this intractable species. Targeting-Induced Local Lesions IN Genomes (TILLING) combines point mutations induced by standard chemical mutagenesis with a sensitive DNA screening technique that identifies single nucleotide polymorphisms (SNPs) in the targeted gene. This reverse-genetic strategy has mainly been used in plants such as Arabidopsis thaliana [7], tomato [8] and Cucurbita pepo [9] but also in parasites such as Toxoplasma gondii [10]. Only one publication reported its use in a bacterium, the intracellular Chlamydia trachomatis species [11].

In this study, we used ethyl methanesulfonate (EMS) that introduces C-G to T-A transition mutations to generate a library of $M$. hominis mutants. As a proof of principle, mutagenized organisms were screened for mutations in two target genes, the vaa gene encoding the variable adherence-associated (Vaa) adhesin lipoprotein [12] and the oppA gene encoding the substrate binding subunit of an oligopeptide permease and the main ectoATPase of the bacteria [13, 14]. The generated vaa- and oppA-mutants were fully sequenced and evaluated using two functional assays, an adhesion test to HeLa cells for vaa-mutants and an ATPase activity test for oppA-mutants.

\section{Results}

Generation of a $M$. hominis mutant library

The effect of EMS on M. hominis survival was assessed after contact times of $1.5 \mathrm{~h}$ and $3 \mathrm{~h}$ (Fig. 1). A positive correlation was observed between the concentration of EMS and the killing of the bacteria. The contact time with EMS also slightly affected the survival of $M$. hominis. For the generation of the mutant library, a concentration of $9 \mathrm{mg} / \mathrm{ml}$ EMS applied for $3 \mathrm{~h}$ that resulted in $75 \%$ killing was chosen according to the bibliography [11]. After culture filtration to avoid bacterial aggregates and plating on agar medium, 1200 individual colonies were picked, grown and frozen.

\section{Screening of the $M$. hominis mutant library for vaa- and oppA-mutants}

To screen the library for vaa-mutants, a 1692-bp PCR fragment of the $M$. hominis genome encompassing the 1295 nucleotides at the $5^{\prime}$-end of the vaa gene (MHO_3470, 1416 bp [2]) was targeted (Table 1, Fig. 2). To screen for oppA-mutants, a 1144-bp PCR fragment of the oppA gene encompassing the regions encoding the CS3, Walker B and Walker A domains involved in ATPase activity [14] of the OppA protein (MHO_1510, 2886 bp) was amplified (Table 1, Fig. 2).

After the screening procedure using ENDO1 nuclease, a total of six vaa and four oppA M. hominis mutants were obtained (Table 2). Four mutants were discarded: (i) two vaa-mutants that harboured a $\mathrm{C}$ to $\mathrm{T}$ transition located upstream of the vaa gene (these mutants were initially screened because the amplified DNA fragment encompassed 397 nucleotides upstream of the gene) and (ii) two oppA-mutants that harboured a G181068A and a G180439A silent substitution, respectively. Overall, four vaa-mutants (Mho66, Mho119, Mho787 and Mho1133) and two oppA-mutants (Mho369 and Mho940), each harbouring one amino-acid substitution in the targeted region of the vaa and $о p p A$ genes, respectively, were selected. The genomes of these six selected mutants were fully sequenced. The expected mutation was found in every mutant and zero to eight additional mutations were retrieved in the whole genome of each mutant (Table 3). Notably, mutant Mho66 harboured no additional mutation and mutant Mho369 harboured only one additional mutation in an intergenic region.

\section{Functional assays applied to vaa- and oppA-mutants}

The four vaa-mutants, Mho66, Mho119, Mho787 and Mho1133, and the parental PG21 M. hominis strain, which has a functional in-frame vaa gene, were tested for adhesion to HeLa cells immobilized on microtiter plates to quantify bacterial adherence. In all cases, the number of adherent $M$. hominis cells increased with the amount of $M$. hominis inoculum used in the assay 


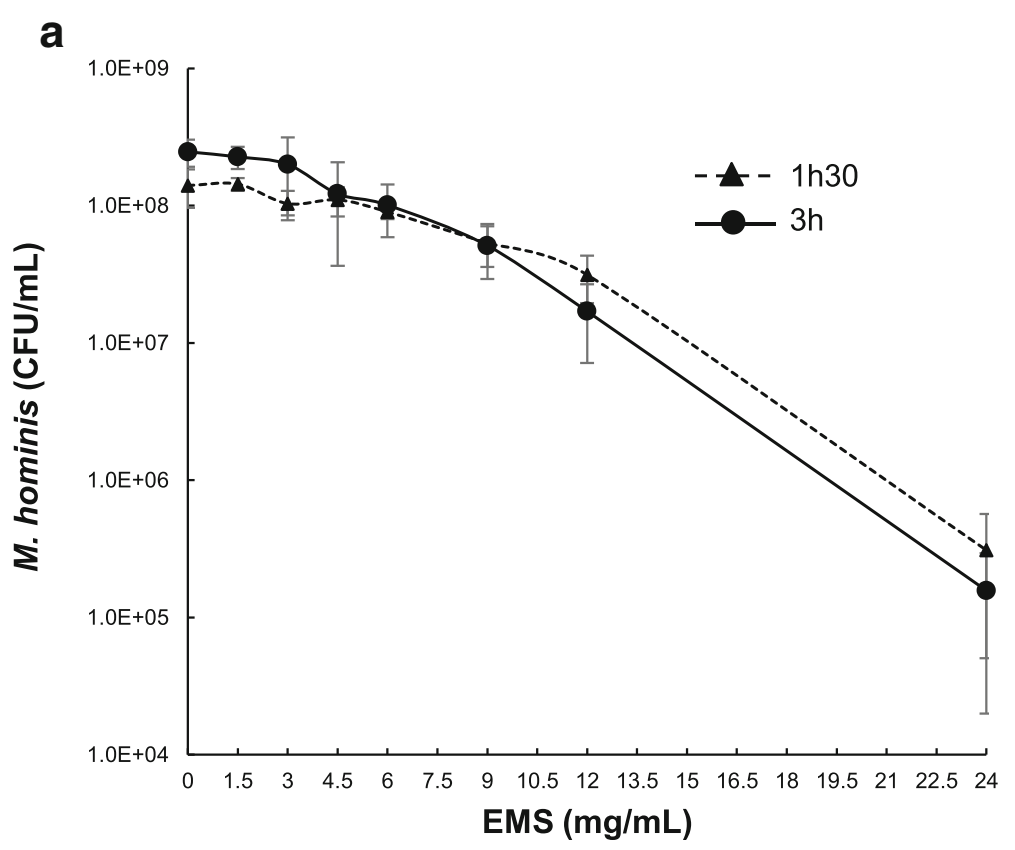

b

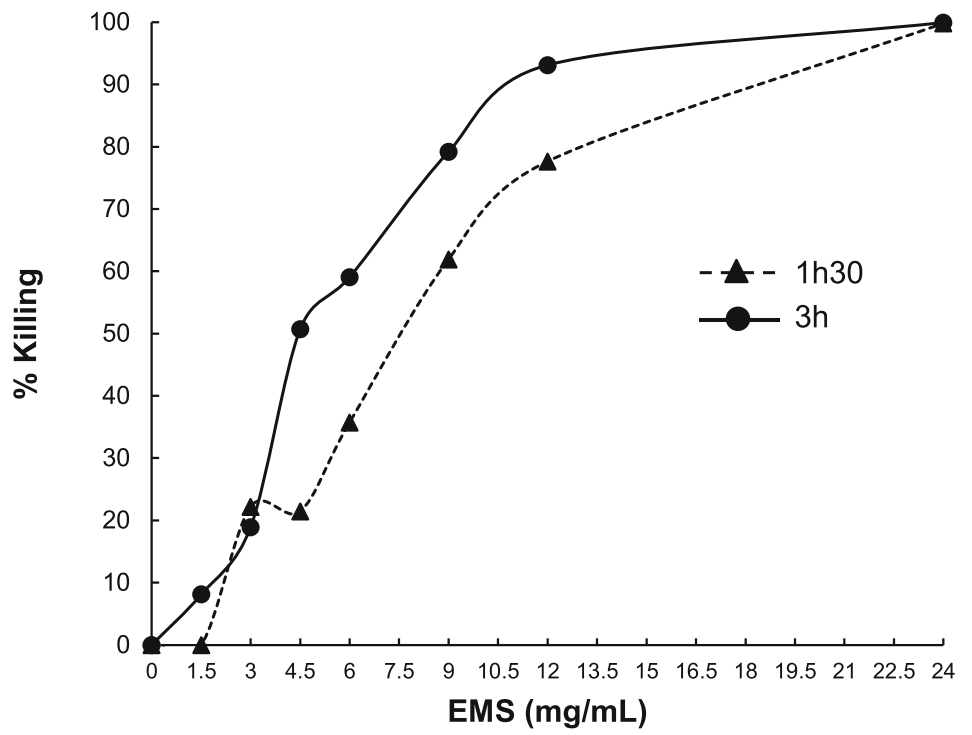

Fig. 1 Effects of EMS mutagenesis on M. hominis survival. Concentrations of M. hominis PG21 were determined after treatment with various concentration of EMS for $1.5 \mathrm{~h}$ and $3 \mathrm{~h}(\mathbf{a})$. Three independent experiments were performed. The percentage of killing was calculated (b). In accordance with the literature, a $75 \%$ killing rate corresponding to exposure to approximately $9 \mathrm{mg} / \mathrm{ml}$ EMS for $3 \mathrm{~h}$ was chosen to generate the M. hominis PG21 mutant library

(Fig. 3). The adhesion of the four vaa-mutants and the non-mutated $M$. hominis PG21 strain was not significantly different ( $p=0.73$, Kruskal-Wallis test).

The two oppA-mutants, Mho369 and Mho940, and the parental PG21 strain were tested for ATPase activity (Fig. 4) during which the kinetics of ATP hydrolysis were analysed by measuring the release of free phosphate [14]. Both mutants had a higher $V_{\max }$ than M. hominis
PG21 and the Mho369 mutant had the lowest Michaelis-Menten $K_{\mathrm{m}}$ constant, although the $95 \%$ confidence intervals were overlapping.

\section{Discussion}

Because the transformation of M. hominis PG21 has so far been elusive, chemical mutagenesis using EMS appears to be an alternative option to create gene-targeted 
Table 1 Oligonucleotides used in this study

\begin{tabular}{lll}
\hline Primer target and designation & Primer sequence & Product size (bp) \\
\hline vaa gene & & \\
VaaPG21-FE & 5'-AATGGGATAGTTAGTAAAGTCGG-3' \\
VaaPG21-RE & 5'-AACCCTACCATTGTCGCTAAGA-3' \\
VaaPG21-FE-IRD700 & 5'-IRD700-AATGGGATAGTTAGTAAAGTCGG-3' \\
VaaPG21-RI-IRD800 & 5'-IRD800-GAAAATCTCCTCGTGCTGATG-3' \\
oppA gene & \\
OppAPG21-FE & 5'-GACAGTGGAAAAGCAGACAC-3' \\
OppAPG21-RE & 5'-AGGAACTAAAATGTCCGGGT-3' \\
OppAPG21-FIIIRD700 & 5'-IRDye700- CATCTTCTGGCCAAGCAACT - 3' \\
OppAPG21-RI-IRD800 & 5'-IRDye800-CAGTCTTGGTATGAATCAAC-3' \\
\hline
\end{tabular}

${ }^{a}$ VaaPG21-FE and VaaPG21-RE primers are located upstream and downstream the vaa gene, respectively

mutants. In several organisms, a positive correlation was observed between the concentrations of EMS applied, the killing of the organism and the mutation frequency obtained $[8,11]$. Only one study has reported the generation of EMS mutants and TILLING strategy in bacteria. Indeed, to generate $C$. trachomatis mutants using EMS, the concentration of EMS that generated a single C-G base pair mutation per genome corresponded to a $75 \%$ killing. Because we also observed a positive correlation between the concentration of EMS and the killing of $M$. hominis, we decided to choose, for the generation of the library, the concentration of EMS that killed approximately $75 \%$ of the $M$. hominis population, i.e. $9 \mathrm{mg} / \mathrm{ml}$ applied for $3 \mathrm{~h}$.

Using these conditions, we demonstrated, after screening the 1200-clone library, that four and two $M$. hominis mutants were successfully generated in two targeted genes previously associated with the bacterium's pathogenicity, the vaa gene involved in cytadherence [12] and the oppA gene involved in oligopeptide binding and the ectoATPase activity [13, 15], respectively. Because the ATPase activity of the OppA protein is due mainly to the CS3, Walker B and Walker A gene regions [14], a fragment of 1144 bp encompassing these regions was chosen. Regarding the vaa gene, a 1692-bp fragment encompassing the $5^{\prime}$-end conserved region of the gene was targeted for this proof of concept experiment because an early premature stop in protein synthesis would have had the greatest effect on loss of Vaa-mediated cytoadhesion. To our knowledge, the substitutions that were found in the mutated Vaa and OppA have never been reported in the alleles present in other $M$. hominis strains.

The four vaa-mutants were tested for adhesion to immobilized HeLa cells [14]. Unfortunately, the

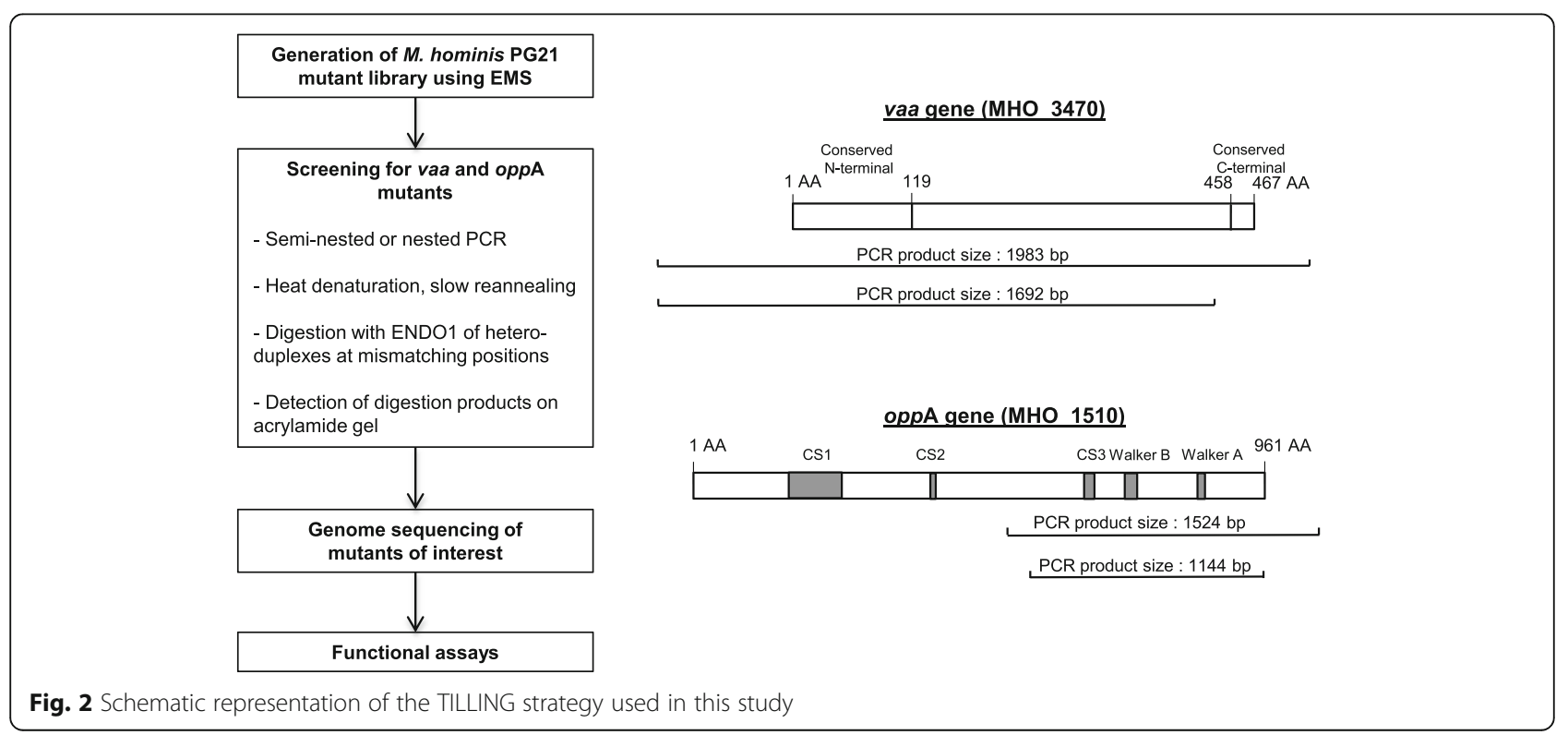


Table 2 vaa- and oppA-mutants obtained by screening the 1200 EMS-generated M. hominis clone library

\begin{tabular}{|c|c|c|c|c|}
\hline Mutant designation & Targeted gene & Nucleotide substitution $^{a}$ & Amino-acid substitution $^{\text {b }}$ & Comments \\
\hline Mho66 & vaa & G410726A & Glu54Lys & \\
\hline Mho119 & vaa & C411332T & Leu328Phe & \\
\hline Mho787 & vaa & C410526A & Pro59His & \\
\hline Mho864 & vaa & C410197T & none & $\begin{array}{l}\text { Mutation located upstream of the } \\
\text { vaa gene (intergenic region) }\end{array}$ \\
\hline Mho1055 & vaa & C410154T & none & $\begin{array}{l}\text { Mutation located upstream of } \\
\text { the vaa gene (intergenic region) }\end{array}$ \\
\hline Mho1133 & vaa & G410726A & Gly126Ser & \\
\hline Mho258 & oppA & G181068A & Leu813Leu & Silent mutation \\
\hline Mho369 & oppA & G180439A & Asp604Asn & \\
\hline Mho785 & oppA & C181239T & Asp870Asp & Silent mutation \\
\hline Mho940 & oppA & G180634A & Glu669Lys & \\
\hline
\end{tabular}

${ }^{a}$ Nucleotide substitutions are numbered according to the $M$. hominis PG21 genome (GenBank accession number FP236530)

${ }^{\mathrm{b}} \mathrm{Amino}$ acid substitutions are numbered from the $\mathrm{N}$-terminal end of the targeted protein

adhesion of the four mutants did not show any significant difference with the adhesion of the parental $M$. hominis PG21 strain. However, because M. hominis harbours several adhesin proteins such as the P120 lipoprotein and the Lmp-related proteins [16], this adhesion assay may not be sensitive enough to detect a potential adhesion decrease caused by the mutation of the Vaa protein. A control strain with an inactivated Vaa protein or a phase variable "OFF" variant would be necessary to determine whether the sensitivity of this assay was

Table 3 Mutations harboured by EMS-generated M. hominis mutants in comparison to the sequence of the M. hominis PG21 strain not exposed to EMS

\begin{tabular}{|c|c|c|c|}
\hline $\begin{array}{l}\text { Mutant } \\
\text { designation }\end{array}$ & $\begin{array}{l}\text { Expected mutation }{ }^{a} \\
\text { (gene, position in the gene) }\end{array}$ & $\begin{array}{l}\text { Other mutations in the genome } \\
\text { (Locus, gene) }\end{array}$ & $\begin{array}{l}\text { Number of additional } \\
\text { mutations }\end{array}$ \\
\hline Mho66 & G410726A (vaa, 376) & none & 0 \\
\hline Mho119 & C411332T (vaa, 982) & $\begin{array}{l}\text { - C230929T (intergenic) } \\
\text { - C316577T (MHO_2640, CHP) } \\
\text { - G463593A (MHO_3770, licA, Protein LicA homolog) } \\
\text { - G494526A (MHO_3990, nusG, Transcription antitermination protein) }\end{array}$ & 4 \\
\hline Mho787 & C410526A (vaa, 176) & $\begin{array}{l}\text { - C5000T (MHO_0050, dnaN, DNA polymerase III beta chain) } \\
\text { - C44025T (MHO_0340, ktrA, Potassium uptake protein KtrA) } \\
\text { - C172081T (MHO_1460, rpsG, 30S ribosomal protein S7) } \\
\text { - C258548T (MHO_2150, rpoD, RNA polymerase sigma factor) } \\
\text { - C283090T (MHO_2320, ABC transporter, ATP-binding protein) } \\
\text { - G288972A (MHO_2370, tRNA/rRNA methyltransferase) } \\
\text { - C441828T (MHO_3650, asnA, Aspartate-ammonia ligase) } \\
\text { - C571686T (MHO_4600, pyrH, Uridylate kinase) }\end{array}$ & 8 \\
\hline Mho1133 & G410726A (vaa, 376) & $\begin{array}{l}\text { - G179389A (MHO_1510, oppA) } \\
\text { - C206418T (MHO_1700, recU, Recombination protein U homolog) } \\
\text { - C381191T (MHO_3200, CHP, Hypothetical lipoprotein) } \\
\text { - G462316A (MHO_3760, gyrB, DNA gyrase subunit B) } \\
\text { - G490546A (intergenic) } \\
\text { - C644067T (MHO_5190, pip, Proline iminopeptidase) }\end{array}$ & 6 \\
\hline Mho369 & G180439A (oppA, 1813) & - G230779A (intergenic) & 1 \\
\hline Mho940 & G180634A (oppA, 2008) & $\begin{array}{l}\text { - G136127A (MHO_1080, ATB-binding protein) } \\
\text { - G138607A (MHO_1090, HP) } \\
\text { - G203092A (MHO_1670, cmk, Cytidylate kinase) } \\
\text { - G211597A (MHO_1740, oppB, Oligopeptide transport system permease } \\
\text { protein) } \\
\text { - A227310G (MHO_1880, aspS, Aspartyl-tRNA synthetase) } \\
\text { - G357674A (MHO_3060, leuS, Leucyl-tRNA synthetase) } \\
\text { - G371725A (MHO_3130, atpA, F1-likeX0) } \\
\text { - G649646C (MHO_5220, hsdS, Type I restriction enzyme specificity protein) }\end{array}$ & 8 \\
\hline
\end{tabular}




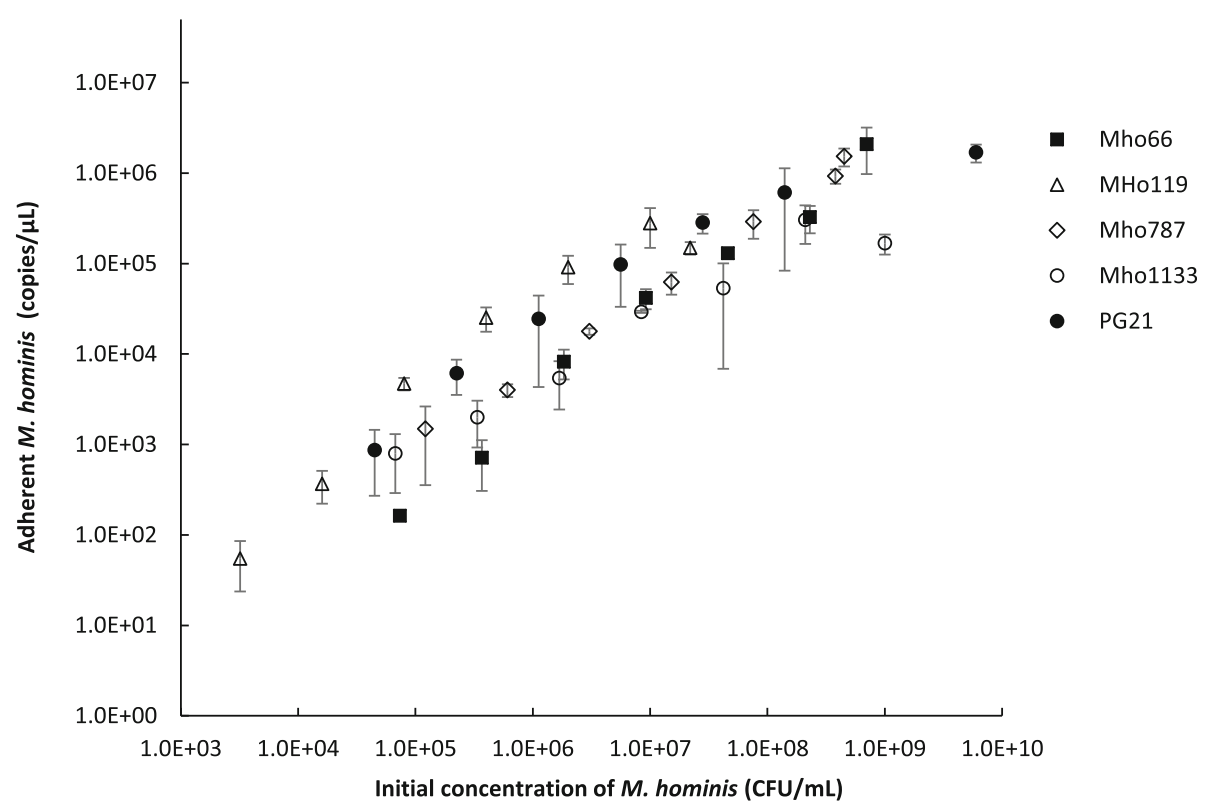

Fig. 3 Adhesion to HeLa cells of EMS-generated M. hominis vaa-mutants. M. hominis cells were added to immobilized HeLa cells in triplicate and incubated $4 \mathrm{~h}$ at $37^{\circ} \mathrm{C}$. After removal of unbound $M$. hominis cells by washing, the adherent M. hominis cells were quantified by real-time PCR. One representative experiment of three is shown

accurate. Analysis of the vaa gene sequence of the $M$. hominis PG21 genome showed that C-G to T-A EMS-generated transitions could theoretically create 23 stop codons, leading to truncated proteins. Thus, enlarging our EMS library may generate null mutants.
Regarding the two oppA-mutants, mutant Mho369 was of interest because (i) it harboured only one additional mutation in an intergenic region of its genome, suggesting that the observed phenotype could be attributed to the EMS-generated oppA mutation with a high



\begin{tabular}{lccc}
\hline & PG21 & Mho369 & Mho940 \\
\hline $\boldsymbol{V}_{\max }$ & $\mathbf{0 . 3 1 3 3}$ & $\mathbf{0 . 5 0 1 3}$ & $\mathbf{0 . 3 9 3 8}$ \\
{$[95 \% \mid C]$} & {$[0.2474-0.3792]$} & {$[0.3177-0.6849]$} & {$[0.3151-0.4724]$} \\
$\boldsymbol{K}_{\mathrm{m}}$ & 0.2642 & $\mathbf{0 . 1 5 4 6}$ & $\mathbf{0 . 3 8 9 8}$ \\
{$[95 \% \mid C]$} & {$[0.0325-0.4959]$} & {$[0.00-0.4529]$} & {$[0.1091-0.6704]$} \\
\hline
\end{tabular}

Fig. 4 ectoATPase activity of EMS-generated M. hominis oppA-mutants. ectoATPase activity of EMS-generated Mho369 and Mho940 M. hominis mutants and of M. hominis PG21 parental strain was determined by measuring the release of free phosphate per $10^{10}$ cells as a function of the ATP concentration. The data represent the means and standard errors of five (Mho369) and four (Mho940 and PG21) independent experiments with triplicate samples in each experiment. $V_{\text {max }}$ maximum rate, $K_{m}$, Michaelis-Menten constant, $95 \%$ IC, $95 \%$ confidence interval 
degree of certainty and (ii) it had a higher $V_{\max }$ and a lower $K_{\mathrm{m}}$ than $M$. hominis PG21, although 95\% confidence intervals were overlapping. This finding suggests that Mho369 may have the capacity to hydrolyse ATP with a higher turnover. This mutant harboured an aspartic acid-to-asparagine substitution located upstream of the CS3 motif, known to be involved in the ATPase activity of the protein [14]. Further studies such as cloning, expression and analysis of the mutated OppA protein could be informative in future works. Nevertheless, although recombinant OppA-mutant proteins have previously been generated [14], oppA-mutated $M$. hominis cells had never been obtained before. Since OppA is involved in M. hominis pathogenicity [13, 15], such mutated M. hominis cells will allow for the characterization of the effect of single amino-acid changes in OppA on the pathogenicity of the mycoplasma.

The TILLING strategy used in this study presents some advantages and some drawbacks. The principal advantage is its capacity to generate gene-targeted mutants in species such as M. hominis that are difficult to genetically manipulate. The ultimate goal of the method is to generate null mutants. All genes could be potentially targeted except those genes that are essential for growth in vitro, and thus cannot be targeted for null mutations. In addition, once a library has been generated, it can be reused to search for mutants in other genes of interest. However, this method is labour-intensive, both for the generation of the library and its handling. The 1200-clone library generated in this study was not representative of the whole $M$. hominis genome and the isolation of a null mutant of Vaa and OppA was not achieved. Sequencing the whole genome of the selected mutants is necessary to check for additional mutations that could have been created in other regions of the chromosome. Indeed, the occurrence of multiple mutations in the same clone may be disruptive for functional studies. However, in a future use of the TILLING strategy, whole genome sequencing will only have to be performed on mutants presenting interesting phenotypes upon functional assays. In the present study, only one of the six sequenced mutants had no other mutation in the genome. Because one to eight additional mutations were present in the five other mutants, it is likely that the concentration and/or the EMS exposure time with $M$. hominis should be decreased slightly in future experiments. Decreasing these parameters would require screening more than 1200 clones to select for a mutant, which would increase the workload of the method. However, the technical improvement of robotic colony pickers may unlock this limitation, making the TILLING strategy a broader avenue for the functional genomic of intractable bacteria.

\section{Conclusion}

Although genetic manipulations are still hardly achievable in $M$. hominis, targeted mutants were successfully generated using the TILLING strategy. Further experiments are needed to adjust the conditions of EMS mutagenesis to limit the mutation frequency to one mutation per genome, but this strategy will be helpful to elucidate the gene functions and to better understand the pathogenesis of this human urogenital species.

\section{Methods}

\section{EMS mutagenesis of $M$. hominis PG21}

The M. hominis PG21 reference strain (ATCC 23114) was grown in Hayflick broth supplemented with arginine (hereafter named Hayflick arginine medium) [17]. One millilitre of a culture of $M$. hominis PG21 ranging between $1 \times 10^{8}$ and $3 \times 10^{8}$ colony forming unit $(\mathrm{CFU}) / \mathrm{ml}$ was exposed to concentrations of EMS ranging from 0 to $24 \mathrm{mg} / \mathrm{ml}$ for $1.5 \mathrm{~h}$ and $3 \mathrm{~h}$ at room temperature, including a 30 -min centrifugation step at $15,000 \mathrm{~g}$. Pellets were resuspended in $1 \mathrm{ml}$ of Hayflick arginine medium, and $M$. hominis concentration was determined by plating on Hayflick agar plates to assess M. hominis survival.

To generate the mutant library, a $10^{8} \mathrm{CFU} / \mathrm{ml} M$. hominis culture was exposed to EMS, filtered on $0.45 \mu \mathrm{m}$ sterile mixed cellulose ester membrane (Millex-HA, Merck Millipore, Cork, Ireland), and $10^{-1}$ to $10^{-4}$ serial dilutions in Hayflick arginine medium were plated on Hayflick agar plates. After $48 \mathrm{~h}$ at $37{ }^{\circ} \mathrm{C}$ under $5 \% \mathrm{CO}_{2}$, individual colonies were picked and grown in $1 \mathrm{ml}$ of Hayflick arginine medium until the colour changed. A total of $800 \mu \mathrm{l}$ of the latter culture was frozen at $-80{ }^{\circ} \mathrm{C}$, and $200 \mu \mathrm{l}$ was used for DNA extraction.

\section{Screening for vaa- and oppA-mutants in M. hominis}

Two hundred microliters from four distinct clone cultures were pooled together before DNA extraction using the MagNA Pure 96 DNA and Viral NA Small Volume kit on the MagNA Pure 96 instrument (Roche Diagnostics, Meylan, France). DNA extraction was also performed on $200 \mu \mathrm{l}$ of each of four single clone cultures when a mutated pool of clones was identified.

PCR fragments of $1692 \mathrm{bp}$ and $1144 \mathrm{bp}$ in regions of interest of the vaa and the oppA genes were amplified by semi-nested and nested PCR, respectively, using primers presented in Table 1 . The first round of PCR was performed on a CFX96 real-time PCR detection system (Bio-Rad Laboratories, Hercules, CA, USA) in a final volume of $25 \mu \mathrm{l}$ using $2.5 \mu \mathrm{M}$ of tartrazine 10X buf-

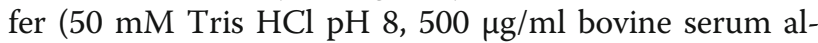
bumin, $0.5 \%$ Ficoll, $1 \%$ sucrose, $30 \mathrm{mM} \mathrm{KCl,} 3 \mathrm{mM}$ $\mathrm{MgCl}_{2}, 1 \mathrm{mM}$ tartrazine), $0.1 \mu \mathrm{M}$ of each primer, $120 \mu \mathrm{M}$ dNTP, $0.0005 \mathrm{U}$ of GoTaq ${ }^{\circ}$ qPCR Master Mix (Promega, Madison, WI, USA), and $1 \mu$ of DNA extract. 
The amplification conditions were $3 \mathrm{~min}$ at $95{ }^{\circ} \mathrm{C}$ followed by 35 cycles of $15 \mathrm{~s}$ at $95{ }^{\circ} \mathrm{C}, 20 \mathrm{~s}$ at $58-68{ }^{\circ} \mathrm{C}$, $2 \mathrm{~min}$ at $72{ }^{\circ} \mathrm{C}$ then $10 \mathrm{~min}$ at $72{ }^{\circ} \mathrm{C}$. The second round of PCR was performed using $0.5 \mu \mathrm{l}$ from the first PCR and IRD700- and IRD800-labelled primers (Table 1). After checking accurate amplification by agarose gel electrophoresis, $5 \mu \mathrm{l}$ of the PCR products was used to screen for vaa- and oppA-mutants. PCR amplicons were heat-denatured $3 \mathrm{~min}$ at $95{ }^{\circ} \mathrm{C}$ and slowly reannealed using a temperature gradient from $95{ }^{\circ} \mathrm{C}$ to $8{ }^{\circ} \mathrm{C}\left(0.1{ }^{\circ} \mathrm{C} /\right.$ s) before a $4{ }^{\circ} \mathrm{C}$ final step. The reannealed amplicons were digested using ENDO1 nuclease at $0.33 \mathrm{U} / \mu \mathrm{l}$, prepared as previously reported [8], for $20 \mathrm{~min}$ at $45^{\circ} \mathrm{C}$ and cooled to $4{ }^{\circ} \mathrm{C}$ to stop the enzyme activity. At this step, if multiple alleles were present in the PCR amplicons, these alleles formed heteroduplexes during reannealing that were specifically cleaved by ENDO1 at mismatching positions. The digested amplicons were purified and dried as described previously [18].

SNP screening was performed using a $\mathrm{LiCOR}^{\circ}$ DNA analyser as previously described [19]. Pools of clones containing vaa- and oppA-mutants were identified by the appearance of lower-mass DNA digestion products after electrophoresis on a $6.5 \%$ acrylamide gel. The PCR products of $v a a$ or oppA genes from the four individual clones of the mutated pool were sequenced by Sanger method (Eurofins Genomics, Ebersberg, Germany) to identify the mutated clone and the mutation type.

\section{M. hominis genome sequencing}

The genomic DNA from four vaa-mutants, two oppA-mutants and from the $M$. hominis PG21 parental strain was extracted using NucleoBond ${ }^{\circ}$ AXG100 columns (Macherey-Nagel, Düren, Germany) and the NucleoBond $^{\bullet}$ buffer Set III (Macherey-Nagel). The genomes were sequenced using paired-end V2 2X250 bp sequencing on MiSeq Illumina apparatus (San Diego, CA, USA) after generating the genomic DNA libraries using the of Nextera XT DNA Library Preparation Kit (Illumina). About 160,000 to 200,000 paired reads were obtained for each genome. Data processing including quality check, trimming, alignment with BWA (Galaxy Version 1.2.3) and variant calling using Varscan (Galaxy Version 0.1) was performed using Galaxy at https://usegalaxy.org/ [20].

\section{Adhesion to HeLa cell assay}

$M$. hominis adhesion to immobilized HeLa cells was performed as previously reported with some modifications [14]. A calibrated culture of each $M$. hominis mutant, with concentrations ranging between $1 \times 10^{8}$ and $4 \times 10^{8}$ $\mathrm{CFU} / \mathrm{ml}$, was concentrated 10 times by centrifugation and serially diluted 1:5 in Hayflick arginine medium. Fifty microliters of each dilution was incubated in triplicate with HeLa cells that had been lysine-coated on 96-well microplates in $50 \mu \mathrm{l}$ of Dulbecco's Modified Eagle's medium (DMEM) supplemented with $1 \%$ fetal bovine serum (DMEM-FBS) for $4 \mathrm{~h}$ at $37^{\circ} \mathrm{C}$. Unbound $M$. hominis cells were removed by three washings with DMEM-FBS. Adherent $M$. hominis cells were lysed using $20 \mu \mathrm{l}$ of proteinase $\mathrm{K} 20 \mathrm{mg} / \mathrm{ml}$ from the NucleoSpin ${ }^{\circ}$ Tissue kit (Macherey-Nagel) for $1 \mathrm{~h}$ at $56{ }^{\circ} \mathrm{C}$ and DNA was extracted using the MagNA Pure 96 DNA and Viral NA Small Volume kit on the MagNA Pure 96 instrument (Roche Diagnostics). A quantitative real-time PCR targeting the $y i d C$ gene of $M$. hominis was then performed as previously described [21]. The non-parametric Kruskal-Wallis test was used to compare the adhesion of mutants and the PG21 parental strain. A significant $p$-value was set at $<0.05$.

\section{ATPase activity test}

The ATPase assay was conducted by incubating $M$. hominis cells with ATP and subsequently using an ammonium molybdate solution to quantify the emerging free phosphates [13]. M. hominis cells were collected from $10 \mathrm{ml}$ of logarithmic growth culture by centrifugation $\left(6700 \mathrm{~g}\right.$ for $10 \mathrm{~min}$ at $\left.6{ }^{\circ} \mathrm{C}\right)$, washed twice in buffer A $(120 \mathrm{mM} \mathrm{NaCl}, 5 \mathrm{mM} \mathrm{KCl}, 20 \mathrm{mM}$ Tris- $\mathrm{HCl}, \mathrm{pH} 7.5)$ and resuspended in $1.2 \mathrm{ml}$ of buffer A. M. hominis cells were quantified by Taqman PCR as published earlier [22]. Triplicates of $20 \mu \mathrm{l}$ of mycoplasma cell suspension and $20 \mu \mathrm{l}$ of buffer A (as negative control) were each adjusted to $0,0.2,0.4,1,2$ or $3 \mathrm{mM}$ ATP and immediately assayed for free phosphate (to estimate phosphate background of mycoplasma suspension) or incubated for $4 \mathrm{~h}$ at $37^{\circ} \mathrm{C}$.

Hydrolysis of ATP was terminated by adding $200 \mu \mathrm{l}$ of malachite green reagent $(5.72 \%[w / v]$ ammonium molybdate in $6 \mathrm{~N} \mathrm{HCl}, 2.32 \%$ [w/v] polyvinyl alcohol, $0.0812 \%$ $[\mathrm{w} / \mathrm{v}]$ malachite green, and distilled water at a ratio of 1:1:2:2). The relative absorbance of the samples was measured in relation to a blank at $620 \mathrm{~nm}$ (Tecan Rainbow, SLT Labinstruments, Crailsheim, Germany). Inorganic phosphate at concentrations ranging from 1 to $20 \mathrm{nmol}$ was used as quantification standard. Values of ATPase activity of $M$. hominis expressed as the release of nmol phosphate were corrected for the phosphate background of ATP, adjusted to $10^{10} \mathrm{M}$. hominis cells and used in the Michaelis-Menten equation to calculate the values of $V_{\max }$ and $K_{\mathrm{m}}$ using the Graph Pad Prism 6.01 software.

\footnotetext{
Abbreviations

C. trachomatis: Chlamydia trachomatis; CHP: Conserved hypothetical protein; EMS: Ethyl methanesulfonate; HP: Hypothetical protein; M. hominis: Mycoplasma hominis; TILLING: Targeting-Induced Local Lesions IN Genomes
} 


\section{Acknowledgements}

The authors thank E. Chancerel for genome sequencing.

\section{Funding}

This study was mainly supported by internal funding. Genome sequencing was performed at the Genome Transcriptome Facility of Bordeaux (PGTB, https://pgtb.cgfb.u-bordeaux.fr/) that is supported by grants from the Conseil Régional d'Aquitaine $n^{\circ} 20030304002 F A$ and $20040305003 F A$, from the European Union FEDER n²003227 and from Investissements d'Avenir ANR10-EQPX-16-01. PGTB staff produced genome sequences of the M. hominis mutants and provided the corresponding FastQ files.

\section{Availability of data and materials}

The PG21 M. hominis reference strain and the EMS-generated M. hominis mutant sequence information were deposited in NCBI Sequence Read Archive (SRA) with the following accession numbers: PG21 (ATCC 23114) SRX4325267, Mho66 SRX4325266, Mho1 19 SRX4325269, Mho369 SRX4325268, Mho787 SRX4325264, Mho940 SRX4325263 and Mho1133 SRX4325265.

\section{Authors' contributions}

SP, PSP, BH and CBéb conceived and designed the study. SP, CBén, CBr, CLR, JPM, FR and BH conducted the experiments and performed data analysis. SP wrote the manuscript with contributions from CBr, PSP, BH and CBéb. All authors read and approved the final manuscript.

\section{Ethics approval and consent to participate}

Not applicable. No human samples and no animals were used.

The M. hominis PG21 reference strain was from ATCC (ATCC 23114). The

HeLa cells were Human cervical carcinoma cell line HeLa S3 (ATCC CCL2.2).

\section{Consent for publication}

Not applicable.

\section{Competing interests}

The authors declare that they have no competing interests.

\section{Publisher's Note}

Springer Nature remains neutral with regard to jurisdictional claims in published maps and institutional affiliations.

\section{Author details}

'USC-EA 3671 Mycoplasmal and Chlamydial Infections in Humans, University of Bordeaux, Campus Bordeaux Carreire, 146 rue Léo Saignat, 33076 Bordeaux Cedex, France. ${ }^{2}$ USC-EA 3671 Mycoplasmal and Chlamydial Infections in Humans, INRA, Bordeaux, France. ${ }^{3}$ Bacteriology department, French National Reference Center for bacterial STI, CHU Bordeaux, Bordeaux, France. ${ }^{4}$ UMR 1332 BFP, INRA, Univ. Bordeaux, F-33140 Villenave d'Ornon, France. ${ }^{5}$ Bordeaux Genome-Transcriptome Facility, F-33610 Cestas, France. ${ }^{6}$ Institute of Medical Microbiology and Hospital Hygiene, Medical Faculty of the Heinrich-Heine-University Duesseldorf, Düsseldorf, Germany.

\section{Received: 20 April 2018 Accepted: 3 July 2018}

Published online: 09 July 2018

\section{References}

1. Waites K, Talkington D. New developments in human diseases due to mycoplasmas. Mycoplasmas: Molecular Biology, Pathogenicity, and Strategies for Control; 2005. p. 289-354.

2. Pereyre $S$, Sirand-Pugnet $P$, Beven $L$, Charron $A$, Renaudin $H$, Barré $A$, Avenaud P, Jacob D, Couloux A, Barbe V, et al. Life on arginine for Mycoplasma hominis: clues from its minimal genome and comparison with other human urogenital mycoplasmas. PLoS Genet. 2009;5(10):e1000677.

3. Roberts MC, Kenny GE. Conjugal transfer of transposon Tn916 from Streptococcus faecalis to Mycoplasma hominis. J Bacteriol. 1987:169(8):3836-9.

4. Dybvig K, French CT, Voelker LL. Construction and use of derivatives of transposon Tn4001 that function in Mycoplasma pulmonis and Mycoplasma arthritidis. J Bacteriol. 2000;182(15):4343-7.
5. Aleksandrova NM, Bevova MR, Govorun VM. Transformation of Mycoplasma hominis with plasmid pAM120 through electroporation. Russ I Genet. 2000; 36(3):237-40.

6. Rideau F, Le Roy C, Descamps ECT, Renaudin H, Lartigue C, Bébéar C. Cloning, stability, and modification of Mycoplasma hominis genome in yeast. ACS Synth Biol. 2017;6(5):891-901.

7. McCallum CM, Comai L, Greene EA, Henikoff S. Targeted screening for induced mutations. Nat Biotechnol. 2000;18(4):455-7.

8. Okabe Y, Asamizu E, Saito T, Matsukura C, Ariizumi T, Bres C, Rothan C, Mizoguchi T, Ezura H. Tomato TILLING technology: development of a reverse genetics tool for the efficient isolation of mutants from micro-tom mutant libraries. Plant Cell Physiol. 2011;52(11):1994-2005.

9. Vicente-Dolera N, Troadec C, Moya M, del Rio-Celestino M, Pomares-Viciana T, Bendahmane A, Pico B, Roman B, Gomez P. First TILLING platform in Cucurbita pepo: a new mutant resource for gene function and crop improvement. PLoS One. 2014;9(11):e112743.

10. Farrell A, Coleman BI, Benenati B, Brown KM, Blader IJ, Marth GT, Gubbels MJ. Whole genome profiling of spontaneous and chemically induced mutations in Toxoplasma gondii. BMC Genomics. 2014;15:354.

11. Kari L, Goheen MM, Randall LB, Taylor LD, Carlson JH, Whitmire WM, Virok $D$, Rajaram K, Endresz V, McClarty G, et al. Generation of targeted Chlamydia trachomatis null mutants. Proc Natl Acad Sci U S A. 2011:108(17):7189-93.

12. Boesen T, Emmersen J, Baczynska A, Birkelund S, Christiansen G. The vaa locus of Mycoplasma hominis contains a divergent genetic islet encoding a putative membrane protein. BMC Microbiol. 2004;4(1):37.

13. Hopfe M, Henrich B. OppA, the substrate-binding subunit of the oligopeptide permease, is the major Ecto-ATPase of Mycoplasma hominis. J Bacteriol. 2004;186(4):1021-8.

14. Hopfe M, Dahlmanns T, Henrich B. In Mycoplasma hominis the OppAmediated cytoadhesion depends on its ATPase activity. BMC Microbiol. 2011;11:185.

15. Hopfe M, Henrich B. OppA, the ecto-ATPase of Mycoplasma hominis induces ATP release and cell death in HeLa cells. BMC Microbiol. 2008;8(1):55.

16. Ladefoged SA. Molecular dissection of Mycoplasma hominis. APMIS. 2000; 108(Suppl. 97:5-45.

17. Waites KB, Bébéar CM, Roberston JA, Talkington DF, Kenny GE. Cumitech 34, laboratory diagnosis of mycoplasmal infections. In: Nolte FS, editor. Cumitech. Washington D. C: American Society for Microbiology. p. 2001.

18. Till BJ, Zerr T, Comai L, Henikoff S. A protocol for TILLING and Ecotilling in plants and animals. Nat Protoc. 2006;1(5):2465-77.

19. Triques K, Piednoir E, Dalmais M, Schmidt J, Le Signor C, Sharkey M, Caboche M, Sturbois B, Bendahmane A. Mutation detection using ENDO1: application to disease diagnostics in humans and TILLING and eco-TILLING in plants. BMC Mol Biol. 2008;9:42.

20. Afgan E, Baker D, Batut B, van den Beek M, Bouvier D, Cech M, Chilton J, Clements D, Coraor N, Gruning BA, et al. The galaxy platform for accessible, reproducible and collaborative biomedical analyses: 2018 update. Nucleic Acids Res. 2018

21. Férandon C, Peuchant O, Janis C, Benard A, Renaudin H, Pereyre S, Bébéar C. Development of a real-time PCR targeting the yidC gene for the detection of Mycoplasma hominis and comparison with quantitative culture. Clin Microbiol Infect. 2011;17(2):155-9.

22. Mobius N, Brenneisen W, Schaeffer A, Henrich B. Protocol for the rapid detection of the urogenital tract mollicutes and Chlamydia with concomitant LGV-(sub)typing. Methods Mol Biol. 2012;903:235-53.

\section{Ready to submit your research? Choose BMC and benefit from:}

- fast, convenient online submission

- thorough peer review by experienced researchers in your field

- rapid publication on acceptance

- support for research data, including large and complex data types

- gold Open Access which fosters wider collaboration and increased citations

- maximum visibility for your research: over $100 \mathrm{M}$ website views per year

\section{At BMC, research is always in progress.}

Learn more biomedcentral.com/submissions 